\title{
A COMPARATIVE STUDY OF DEXMEDETOMIDINE AND CLONIDINE TO ATTENUATE HAEMODYNAMIC RESPONSE DURING LARYNGOSCOPY AND INTUBATION
}

\author{
Balwinder Kaur1, Hardeep Bariar², Parmod Kumar ${ }^{3}$, Sahil Garg ${ }^{4}$, Charu Sharma 5 , Lalit Kumar 6
}

1 Professor, Department of Anaesthesia, RH, Patiala, Punjab.

${ }^{2}$ Associate Professor, Department of Anaesthesia, $R H$, Patiala, Punjab.

3 Professor and HOD, Department of Anaesthesia, RH, Patiala, Punjab.

4Junior Resident, Department of Anaesthesia, RH, Patiala, Punjab.

5Junior Resident, Department of Anaesthesia, RH, Patiala, Punjab.

${ }^{6}$ Medical Officer, PCMS-I, Punjab.

\section{BACKGROUND}

\section{ABSTRACT}

Laryngoscopy and tracheal intubation after the induction of anaesthesia are nearly always associated with a sympathetic hyperactivity. To attenuate the pressor response various drugs have been tried, but these drugs were either partially effective or they produced undesirable effects.

This study aims to compare the effects of Dexmedetomidine $(0.5 \mu \mathrm{g} / \mathrm{kg})$ and Clonidine $(0.5 \mu \mathrm{g} / \mathrm{kg})$ on haemodynamic responses to endotracheal intubation, effect on anaesthetic requirements and effect on sedation.

\section{MATERIALS AND METHODS}

In this prospective, randomised, clinical trial, 100 patients of either sex, aged 20 - 60 years of ASA grade I and II scheduled for elective surgeries under general anaesthesia were randomly divided into two groups Group D (Inj. Dexmedetomidine dose $0.5 \mu \mathrm{g} / \mathrm{kg}$ IV in $100 \mathrm{~mL}$ normal saline) and Group C (Inj. Clonidine dose $0.5 \mu \mathrm{g} / \mathrm{kg}$ IV in $100 \mathrm{~mL}$ normal saline). Haemodynamic parameters (HR, SBP, DBP, MAP, SpO2) were monitored continuously and recorded before the start of infusion, at the start of infusion, at 5 mins of start of infusion, at 10 mins of start of infusion, at intubation and then at 1, 3, 5 and 10 minutes after intubation.

\section{RESULTS}

Magnitude of increase in heart rate at intubation and 1 min after intubation was higher in Group C as compared to Group D and this was statistically significant. Group C had significant rise in SBP and DBP during intubation and at 1, 3, 5 and 10 mins after intubation as compared to Group D. Significant reduction in dose is required for induction in Group D than in Group C.

\section{CONCLUSION}

Dexmedetomidine significantly attenuated the sympathetic response of laryngoscopy and intubation as compared to clonidine.

\section{KEY WORDS}

Dexmedetomidine; Clonidine; Haemodynamic; Laryngoscopy.

HOW TO CITE THIS ARTICLE: Kaur B, Bariar H, Kumar P, et al. A comparative study of dexmedetomidine and clonidine to attenuate haemodynamic response during laryngoscopy and intubation. J. Evolution Med. Dent. Sci. 2018;7(19):2404-2409, DOI: $10.14260 /$ jemds/2018/541

\section{BACKGROUND}

General anaesthesia is a drug-induced reversible condition composed of four behavioural and physiologic states: Unconsciousness, amnesia, analgesia, immobility and stability of the physiologic systems including the autonomic, cardiovascular, respiratory and thermoregulatory systems.[1] Induction is a critical phase of general anaesthesia.[2] Anaesthesia induction is commonly initiated by intravenous administration of hypnotics for abruptly bringing wakeful patients into unresponsiveness to strong adrenergic stimuli including endotracheal intubation and surgical procedures. ${ }^{[3]}$

In 1940, Reid and Brace first described haemodynamic response to laryngoscopy and intubation. ${ }^{[4]}$ The magnitude of response is greater with increasing force and duration of

'Financial or Other Competing Interest': None.

Submission 23-03-2018, Peer Review 18-04-2018,

Acceptance 24-04-2018, Published 07-05-2018.

Corresponding Author:

Dr. Hardeep Bariar,

\#18, Aman Vihar Street,

No. 2, Bhadson Road, Patiala-147001, Punjab.

E-mail:drhardeepbariar@gmail.com

DOI: $10.14260 /$ jemds $/ 2018 / 541$

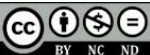

laryngoscopy.[5] The rise in blood pressure and pulse are usually transitory, variable and unpredictable. These effects may have serious repercussions on the high risk patients like those with hypertension, heart disease and coronary artery disease. Therefore, attenuation of such responses is of great importance in the prevention of the perioperative morbidity and mortality.[6]

Many non-pharmacological (Smooth and gentle intubation with shorter duration of laryngoscopy, insertion of LMA in place of endotracheal intubation and blocking glossopharyngeal and superior laryngeal nerves) and pharmacological methods (Use of inhalational anaesthetics, pre-treatment with IV lidocaine, narcotics, topical anaesthesia, beta blockers, calcium channel blockers, ACE inhibitors, vasodilators etc.) have been tried by various authors to attenuate the cardiovascular response to laryngoscopy.[4,7-11]

None of these approaches or agents have proved to be ideal. Hence, the search for an ideal agent to attenuate haemodynamic response is still continuing. Since sedation, anxiolytic and anti-sialagogue action are attractive attributes in a premedication prior to anaesthesia, administration of alpha-2 agonists suits this purpose well.[12] Both clonidine and dexmedetomidine and clonidine have actions on both alpha-1 
and alpha- 2 receptors, but dexmedetomidine is highly specific and selective alpha-2 adrenoceptor agonist with alpha-2: alpha-1 binding selectivity ratio of 1620: 1 compared to 220: 1 for clonidine.[13]

Dexmedetomidine (Dextro-isomer of medetomidine) was introduced in 1999 and its advantages include sedation, analgesia, anxiolysis and improved haemodynamic stability by the activation of alpha- 2 receptor located in the postsynaptic terminals in the central nervous system, which causes augmentation of vagal activity.[14-17]

Premedication with clonidine blunts the stress response to surgical stimuli and requirement of the narcotic and anaesthetic drug are also reduced. In addition, clonidine increases cardiac baroreceptor reflex sensitivity to increase in systolic blood pressure and thus stabilises blood pressure. Thus, clonidine improves perioperative haemodynamic responses to surgical stimulation, to induce sedation, to decrease anaesthetic requirement and to modulate pain pathways in spinal cord resulting in analgesia. But its relatively long half-life of 6 - 10 hours has limited its use in comparison to dexmedetomidine which has half-life of only 23 hours and is more selective ( 7 - 8 times) at $\alpha 2$ receptors. ${ }^{[18,19]}$

The present study was aimed at attenuation of the haemodynamic response to laryngoscopy and intubation in adult patients posted for elective surgeries under general anaesthesia using single IV bolus low dose of dexmedetomidine or clonidine given over 10 mins before induction of anaesthesia.

\section{MATERIALS AND METHODS}

This prospective randomised clinical trial- "A comparative study of Dexmedetomidine and Clonidine to attenuate haemodynamic response during laryngoscopy and intubation" was carried out after obtaining ethical committee clearance as well as written informed consent from all patients. 100 patients of either sex, aged 20 - 60 years of ASA grade I and II scheduled for elective surgeries under general anaesthesia at Govt. Medical College, Rajindra Hospital, Patiala were included. The patients were randomly divided into 2 groups (Group D and Group C) of 50 each by simple randomisation was done using lottery method. (Group D received dexmedetomidine and Group $\mathrm{C}$ received clonidine).

Inclusion criteria were age 20 - 60 years, ASA grade I and II, elective surgical procedure under general anaesthesia, Mallampati grade 1 and 2, patient willing to participate in this study. Exclusion criteria were patient refusal, history of bradycardia (Heart Rate $<50 \mathrm{bpm}$ ), history of renal or liver dysfunction, history of previous cerebrovascular accident, history of coronary artery disease, pregnant and lactating patients.

A written informed consent was obtained from each patient after explaining the anaesthetic technique prior to inclusion in this study in their own vernacular language. Patients were randomly divided into 2 groups (Group D and Group C) of 50 each. Group D patients received $0.5 \mu \mathrm{g} / \mathrm{kg}$ of IV Dexmedetomidine in $100 \mathrm{~mL}$ normal saline infused over 10 mins before laryngoscopy and intubation. Group $\mathrm{C}$ patients received $0.5 \mu \mathrm{g} / \mathrm{kg}$ of IV Clonidine in $100 \mathrm{~mL}$ normal saline infused over 10 mins before laryngoscopy and intubation.
Pre-anaesthetic check-up and routine investigation $\mathrm{CHb} \%$, BT, CT, Blood grouping, Urine analysis, ECG, BUN, Serum creatinine and Fasting blood sugar) were done one day before surgery in every patient. Each patient was kept fasting for at least six hours pre-operative and received tablet lorazepam $1 \mathrm{mg}$ at 6 am on the day of surgery.

After routine check-up of anaesthesia machine, circuit and resuscitation equipment, fasting patients were shifted to OT and were connected to multichannel monitor. Two IV lines were secured with 18-G cannula and preloading with $500 \mathrm{~mL}$ ringer lactate was done over 30 mins for all the patients. Basal Systolic Blood Pressure (SBP), Diastolic Blood Pressure (DBP), Mean Arterial Pressure (MAP), Heart Rate (HR) and $\mathrm{SpO}_{2}$ were recorded after 5 mins of settling in OT (T0). Rhythm monitoring from a continuous visual display of ECG along with continuous monitoring of the vital parameters was done.

Following this, patients of Group D received IV dexmedetomidine $0.5 \mu \mathrm{g} / \mathrm{kg}$ in $100 \mathrm{~mL}$ NS to be infused over 10 mins. Patients of Group C received IV clonidine $0.5 \mu \mathrm{g} / \mathrm{kg}$ in $100 \mathrm{~mL}$ NS to be infused over 10 mins. HR, SBP, DBP, MAP and $\mathrm{SpO}_{2}$ were monitored continuously, but recorded/documented at the start of infusion (T1) at 5 mins of start of infusion (T2) and at 10 mins of start of infusion i.e. completion of infusion (T3) in both groups.

Prior to induction Inj. Glycopyrrolate $0.2 \mathrm{mg}$, Inj. Ondansetron $4 \mathrm{mg}$ and Inj. Ranitidine $50 \mathrm{mg}$ was given intravenously. After pre-oxygenation with $100 \%$ Oxygen, all patients were induced with IV anaesthetic agent propofol and inhalational agent isoflurane. The dose of propofol was controlled by loss of eyelash and corneal reflex followed by succinylcholine $2 \mathrm{mg} / \mathrm{kg}$ to facilitate endotracheal intubation. Patients were intubated with an appropriate sized, orally cuffed, disposable endotracheal tube.

Anaesthesia was maintained with intermittent positive pressure ventilation using Bain's circuit with appropriate mixture of $\mathrm{N}_{2} \mathrm{O}$ and $\mathrm{O}_{2}$, Isoflurane and using Inj. vecuronium bromide $0.08 \mathrm{mg} / \mathrm{kg}$ to $0.1 \mathrm{mg} / \mathrm{kg}$ IV bolus followed by maintenance dose 1/4th of the initial dose depending upon requirement. Cardiovascular parameters (HR, SBP, DBP, MAP, Sp02, EtCo2) were recorded during laryngoscopy and intubation (T4) and at 1, 3, 5 and 10 mins after laryngoscopy and intubation (T5 to T8) and then after every 10 mins interval intraoperative till the end of surgery.

\begin{tabular}{|c|c|}
\hline $\begin{array}{c}\text { Response to Vital Parameters during } \\
\text { Infusion of Dexmedetomidine/ } \\
\text { Clonidine }\end{array}$ & $\begin{array}{c}\text { HR, SBP, DBP, MAP, } \\
\mathbf{S p O}_{2}, \mathbf{E t C o}_{2} \\
\text { Recording }\end{array}$ \\
\hline $\begin{array}{c}\text { Basal reading after 5 mins of patient } \\
\text { being shifted to 0T }\end{array}$ & $\mathrm{T}_{0}$ \\
\hline $\begin{array}{c}\text { At the start of infusion of } \\
\text { dexmedetomidine/ clonidine }\end{array}$ & $\mathrm{T}_{1}$ \\
\hline $\begin{array}{c}\text { At } 5 \text { mins after infusion of } \\
\text { dexmedetomidine/ clonidine }\end{array}$ & $\mathrm{T}_{2}$ \\
\hline $\begin{array}{c}\text { At 10 mins/ completion after infusion } \\
\text { of dexmedetomidine/ clonidine }\end{array}$ & $\mathrm{T}_{3}$ \\
\hline Table A \\
\hline
\end{tabular}




\begin{tabular}{|c|c|}
\hline $\begin{array}{l}\text { Response to Vital Parameters after } \\
\text { Infusion of Dexmedetomidine/ Clonidine }\end{array}$ & $\begin{array}{c}\text { HR, SBP, DBP, } \\
\text { MAP, SpO } \\
\text { EtCo } \\
\text { Recording } \\
\text { Recoling }\end{array}$ \\
\hline During laryngoscopy and intubation & $\mathrm{T}_{4}$ \\
\hline At 1 min after laryngoscopy and intubation & $\mathrm{T}_{5}$ \\
\hline At 3 mins after laryngoscopy and intubation & $\mathrm{T}_{6}$ \\
\hline At 5 mins after laryngoscopy and intubation & $\mathrm{T}_{7}$ \\
\hline $\begin{array}{c}\text { At } 10 \text { mins after laryngoscopy and } \\
\text { intubation }\end{array}$ & $\mathrm{T}_{8}$ \\
\hline
\end{tabular}

The concentration of isoflurane was adjusted to maintain systolic blood pressure (SBP) within $20 \%$ of the preoperative values.

At the end of surgery, neuromuscular blockade was reversed with neostigmine $50 \mu \mathrm{g} / \mathrm{kg}$ and glycopyrrolate $10 \mu \mathrm{g} / \mathrm{kg}$ intravenously. After satisfying the extubation criteria, patients were extubated and transferred to post-anaesthesia care unit (PACU).

In PACU, HR, SBP, DBP, MAP, $\mathrm{SpO}_{2}$, sedation score and any incidence of complications/ adverse event was monitored for next 90 mins at interval of 10 mins. Once the patient was shifted to PACU, first reading was taken as $0 \mathrm{~min}$ and then after every 10 mins till 90 mins. Modified Aldrete scoring > 9 was considered criteria for shifting the patients to ward from PACU.

Fall in BP $20 \%$ below baseline was considered as hypotension and was managed appropriately. Pulse rate lower than 50 beats per minute (bpm) was regarded as bradycardia and was managed with atropine $(0.3-0.6 \mathrm{mg})$. Fall in saturation was managed meticulously depending upon the cause. Rise or fall in $\mathrm{EtCo}_{2}$ was managed accordingly depending upon the cause.

Sedation scoring was done as per Ramsay sedation scale after completion of drug infusion. Adverse effects (hypotension, bradycardia, arrhythmia) if any were treated and recorded.

Descriptive statistics was done for all data and suitable statistical tests of comparison were done. Continuous variables were analysed with unpaired t-test and MannWhitney $U$ test. Categorical variables were analysed with the Chi-square test. Statistical significance was taken as $P$ value $<0.05$, statistical highly significant was taken as $P$ value $<0.001$, statistical non-significant was taken as $P$ value $>0.05$. The observations were depicted in tables. The data was analysed using IBMM SPSS statistics (22.00 version) and Microsoft Excel 2007.

\section{Sample Size Calculation}

Sample size was estimated based on pilot study. We see that mean difference in heart rate in 2 groups was 4.06 with SD of 7.05. With this our sample size $n=48$ per group at a power of $80 \%$ and confidence interval of $95 \%$. For possible dropouts, it was decided to include 50 patients per group.

$\mathrm{N}=2 \sigma^{2}\left(\mathrm{Z}_{1-\alpha / 2}+\mathrm{Z}_{1-\beta}\right)^{2} / \Delta^{2}$ where $\mathrm{Z}_{1-\alpha / 2}$ is the critical value of the Normal distribution at $1-\alpha / 2, Z_{1-\beta}$ is the critical value of the Normal distribution at $1-\beta, \sigma^{2}$ is the population variance and $\Delta$ is difference between 2 means.

\section{RESULTS}

The present study has been designed to compare the effect of dexmedetomidine and clonidine to attenuate haemodynamic response during laryngoscopy and intubation in patients undergoing elective surgeries under general anaesthesia at Government Medical College, Rajindra Hospital, Patiala. The study has been conducted in 100 patients randomly divided into two groups Group D (Dexmedetomidine $0.5 \mu \mathrm{g} / \mathrm{kg}$ ) and Group C (Clonidine $0.5 \mu \mathrm{g} / \mathrm{kg}$ ) of 50 patients each comparable in terms of demographic parameters, ASA grading (Ref: Table No. 1) and baseline haemodynamic parameters.

\begin{tabular}{|c|c|c|c|c|c|c|}
\hline \multirow{2}{*}{ Variable } & \multicolumn{2}{|c|}{ Group D } & \multicolumn{2}{|c|}{ Group C } & \multirow{2}{*}{$\begin{array}{c}P \\
\text { value }\end{array}$} & \multirow{2}{*}{ Significance } \\
\hline & Mean & S.D. & Mean & S.D. & & \\
\hline $\begin{array}{c}\text { Age (yrs.) } \\
\text { \{Unpaired T } \\
\text { test }\end{array}$ & 41.30 & 10.90 & 41.36 & 11.98 & 0.979 & NS \\
\hline $\begin{array}{c}\text { Sex (M/F) } \\
\{\text { Chi-square }\}\end{array}$ & $10 / 40$ & & $12 / 38$ & & 0.629 & NS \\
\hline $\begin{array}{c}\text { ASA grade } \\
\text { (I/II) } \\
\text { \{Chi-square }\}\end{array}$ & $26 / 24$ & & $25 / 25$ & & 0.841 & NS \\
\hline $\begin{array}{l}\text { Body weight } \\
\text { (kg) } \\
\text { \{Unpaired } \mathrm{T} \\
\text { test\} }\end{array}$ & 67.42 & 7.33 & 68.00 & 4.96 & 0.644 & NS \\
\hline $\begin{array}{l}\text { Duration of } \\
\text { surgery } \\
\text { (mins) } \\
\text { \{Unpaired T } \\
\text { test\} }\end{array}$ & 77.32 & 17.68 & 75.76 & 31.02 & 0.758 & NS \\
\hline
\end{tabular}

\section{Abbreviations}

M: Male; F: Female; ASA: American Society of Anesthesiologists; NS: Not Significant; S.D: Standard Deviation

\begin{tabular}{|c|c|c|c|c|c|c|}
\hline $\begin{array}{c}\text { HR } \\
\text { (bpm) }\end{array}$ & \multicolumn{2}{|c|}{ Group D } & \multicolumn{2}{c|}{ Group C } & \multirow{2}{*}{ P value Significance } \\
\hline $\mathbf{T}_{\mathbf{0}}$ & 87.66 & 11.793 & 83.72 & 10.325 & 0.059 & $\mathrm{NS}$ \\
\hline $\mathbf{T}_{\mathbf{1}}$ & 87.92 & 12.270 & 84.32 & 9.999 & 0.066 & $\mathrm{NS}$ \\
\hline $\mathbf{T}_{\mathbf{2}}$ & 85.32 & 12.188 & 83.58 & 10.033 & 0.242 & $\mathrm{NS}$ \\
\hline $\mathbf{T}_{\mathbf{3}}$ & 83.92 & 11.733 & 82.24 & 14.767 & 0.492 & $\mathrm{NS}$ \\
\hline $\mathbf{T}_{\mathbf{4}}$ & 95.14 & 9.600 & 100.06 & 8.049 & 0.013 & S \\
\hline $\mathbf{T}_{\mathbf{5}}$ & 88.26 & 8.898 & 93.00 & 7.466 & 0.005 & $\mathrm{HS}$ \\
\hline $\mathbf{T}_{\mathbf{6}}$ & 87.92 & 8.231 & 88.98 & 8.193 & 0.451 & $\mathrm{NS}$ \\
\hline $\mathbf{T}_{\mathbf{7}}$ & 86.98 & 8.277 & 86.88 & 7.148 & 0.830 & $\mathrm{NS}$ \\
\hline $\mathbf{T}_{\mathbf{8}}$ & 86.46 & 10.448 & 86.08 & 6.442 & 0.849 & $\mathrm{NS}$ \\
\hline Table 2. Comparison of Changes in Mean Heart Rate \\
\hline \multicolumn{8}{|c|}{} \\
\hline
\end{tabular}

\section{Abbreviations}

HR: Heart Rate; NS: Not Significant; S: Significant; HS: Highly Significant; S.D: Standard Deviation.

\begin{tabular}{|c|c|c|c|c|c|c|}
\hline SBP & \multicolumn{2}{|c|}{ Group D } & \multicolumn{2}{c|}{ Group C } & \multirow{2}{*}{ P value } & \multirow{2}{*}{ Significance } \\
\cline { 2 - 7 }$(\mathbf{m m H g})$ & Mean & S.D & Mean & S.D & & \\
\hline $\mathbf{T}_{\mathbf{0}}$ & 126.00 & 9.897 & 127.72 & 9.781 & 0.354 & NS \\
\hline $\mathbf{T}_{\mathbf{1}}$ & 124.88 & 9.766 & 127.04 & 9.243 & 0.258 & NS \\
\hline $\mathbf{T}_{\mathbf{2}}$ & 121.08 & 9.357 & 124.56 & 9.537 & 0.067 & NS \\
\hline $\mathbf{T}_{\mathbf{3}}$ & 117.60 & 11.766 & 122.24 & 8.756 & 0.085 & NS \\
\hline $\mathbf{T}_{\mathbf{4}}$ & 135.80 & 10.095 & 141.76 & 8.530 & $<0.001$ & HS \\
\hline $\mathbf{T}_{\mathbf{5}}$ & 124.96 & 9.118 & 131.04 & 7.343 & $<0.001$ & HS \\
\hline $\mathbf{T}_{\mathbf{6}}$ & 122.64 & 7.199 & 128.56 & 7.835 & $<0.001$ & HS \\
\hline $\mathbf{T}_{\mathbf{7}}$ & 121.32 & 5.563 & 124.96 & 6.184 & 0.003 & HS \\
\hline $\mathbf{T}_{\mathbf{8}}$ & 120.92 & 6.327 & 124.04 & 5.763 & 0.011 & S \\
\hline Table 3. Comparison of Changes in Systolic Blood Pressure \\
\hline
\end{tabular}




\section{Abbreviations}

SBP: Systolic Blood Pressure; NS: Not Significant; S: Significant; HS: Highly Significant; S.D: Standard Deviation.

\begin{tabular}{|c|c|c|c|c|c|c|}
\hline $\begin{array}{c}\text { DBP } \\
\text { (mmHg) }\end{array}$ & \multicolumn{2}{|c|}{ Group D } & \multicolumn{2}{c|}{ Group C } & P & \multirow{2}{*}{ Significance } \\
\cline { 2 - 6 } $\mathrm{T}_{0}$ & 83.72 & 5.361 & 83.68 & 6.790 & 0.654 & $\mathrm{NS}$ \\
\hline $\mathrm{T}_{1}$ & 82.88 & 6.236 & 84.76 & 6.784 & 0.283 & $\mathrm{NS}$ \\
\hline $\mathrm{T}_{2}$ & 81.12 & 5.844 & 82.54 & 6.938 & 0.410 & $\mathrm{NS}$ \\
\hline $\mathrm{T}_{3}$ & 78.98 & 5.730 & 80.66 & 6.589 & 0.110 & $\mathrm{NS}$ \\
\hline $\mathrm{T}_{4}$ & 91.72 & 5.345 & 96.00 & 5.686 & $<0.001$ & $\mathrm{HS}$ \\
\hline $\mathrm{T}_{5}$ & 84.56 & 7.451 & 89.28 & 6.151 & 0.001 & $\mathrm{HS}$ \\
\hline $\mathrm{T}_{6}$ & 81.48 & 6.487 & 85.48 & 12.066 & 0.042 & $\mathrm{~S}$ \\
\hline $\mathrm{T}_{7}$ & 82.68 & 6.864 & 85.64 & 5.153 & 0.017 & $\mathrm{~S}$ \\
\hline $\mathrm{T}_{8}$ & 81.38 & 6.746 & 83.96 & 4.857 & 0.031 & $\mathrm{~S}$ \\
\hline \multicolumn{7}{|c|}{ Table 4. Comparison of Changes in Diastolic Blood } \\
\hline \multicolumn{8}{|c|}{ Pressure } \\
\hline
\end{tabular}

\section{Abbreviations}

DBP: Diastolic Blood Pressure; NS: Not Significant; S: Significant; HS: Highly Significant; S.D: Standard Deviation.

\begin{tabular}{|c|c|c|c|c|c|c|}
\hline $\begin{array}{c}\text { MAP } \\
\text { (mmHg) }\end{array}$ & \multicolumn{2}{|c|}{ Group D } & \multicolumn{2}{c|}{ Group C } & P & \multirow{2}{*}{ Significance } \\
\cline { 2 - 5 } $\mathrm{T}_{0}$ & 97.81 & 6.283 & 98.36 & 7.090 & 0.882 & NS \\
\hline $\mathrm{T}_{1}$ & 96.88 & 6.736 & 98.85 & 6.916 & 0.164 & $\mathrm{NS}$ \\
\hline $\mathrm{T}_{2}$ & 94.44 & 6.135 & 96.55 & 7.239 & 0.143 & $\mathrm{NS}$ \\
\hline $\mathrm{T}_{3}$ & 91.85 & 6.894 & 94.52 & 6.687 & 0.075 & $\mathrm{NS}$ \\
\hline $\mathrm{T}_{4}$ & 106.41 & 6.058 & 111.25 & 5.720 & $<0.001$ & $\mathrm{HS}$ \\
\hline $\mathrm{T}_{5}$ & 98.12 & 6.740 & 103.20 & 5.774 & $<0.001$ & $\mathrm{HS}$ \\
\hline $\mathrm{T}_{6}$ & 95.20 & 5.835 & 99.84 & 8.673 & 0.002 & $\mathrm{HS}$ \\
\hline $\mathrm{T}_{7}$ & 95.56 & 5.820 & 98.74 & 4.478 & 0.003 & $\mathrm{HS}$ \\
\hline $\mathrm{T}_{8}$ & 94.56 & 5.654 & 97.32 & 4.232 & 0.007 & $\mathrm{HS}$ \\
\hline Table 5. Comparison of Changes in Mean Arterial Blood \\
\multicolumn{8}{|c|}{ Pressure } \\
\hline
\end{tabular}

\section{Abbreviations}

MAP: Mean arterial blood pressure; NS: Not Significant; HS: Highly Significant; S.D: Standard Deviation.

\begin{tabular}{|c|c|c|c|c|c|c|}
\hline \multirow{2}{*}{ Variable } & \multicolumn{2}{|c|}{ Group D } & \multicolumn{2}{|c|}{ Group C } & $\begin{array}{c}\text { P } \\
\text { value }\end{array}$ & Significance \\
\cline { 2 - 5 } & Mean & S.D. & Mean & S.D. & & \\
\hline $\begin{array}{c}\text { IV Propofol } \\
\text { Induction } \\
\text { dose (mg) } \\
\text { \{Mann- } \\
\text { Whitney U } \\
\text { test\} }\end{array}$ & 102.20 & 13.29 & 107.80 & 11.48 & 0.023 & $\mathrm{~S}$ \\
\hline $\begin{array}{c}\text { Ramsay } \\
\text { Sedation } \\
\text { Scale }\end{array}$ & 2.06 & 0.239 & 2.04 & 0.197 & 0.648 & NS \\
\hline $\begin{array}{c}\text { Table 6. Comparison of Induction Dose of Propofol and } \\
\text { Ramsay Sedation Scale }\end{array}$ \\
\hline
\end{tabular}

\section{Abbreviations}

IV: Intravenous; NS: Not Significant; S: Significant; SD: Standard deviation.

\begin{tabular}{|c|c|c|c|c|c|c|}
\hline \multirow{2}{*}{ MAS } & \multicolumn{2}{|c|}{ Group D } & \multicolumn{2}{c|}{ Group C } & \multirow{2}{*}{ P value } & Significance \\
\cline { 2 - 6 } & Mean & S.D. & Mean & S.D. & & \\
\hline $0 \mathrm{~min}$ & 9.82 & .388 & 9.86 & .351 & 0.587 & NS \\
\hline $10 \mathrm{~min}$ & 9.98 & .141 & 10.00 & 0.00 & 0.317 & NS \\
\hline $20 \mathrm{~min}$ & 10.00 & 0.00 & 10.00 & 0.00 & - & - \\
\hline \multicolumn{7}{|c|}{ Table 7. Comparison of Modified Aldrete Score } \\
\hline
\end{tabular}

\section{Abbreviations}

MAS: Modified Aldrete Score; NS: Not Significant; S.D: Standard Deviation.

Haemodynamic parameters including Heart Rate, SBP, DBP, MAP, Sp02 were recorded at T0, T1, T2, T3, T4, T5, T6, T7, T8 and then after every 10 mins, Interval Intraoperative upto 120 mins-

- $\quad$ T0: Basal reading after 5 mins of patient being shifted to OT.

- T1: At the start of infusion of dexmedetomidine/clonidine.

- T2: At 5 mins after infusion of dexmedetomidine/clonidine.

- T3: At 10 mins/completion after infusion of dexmedetomidine/ clonidine.

- T4: During laryngoscopy and intubation.

- T5-T8: At 1, 3, 5, 10 mins after laryngoscopy and intubation.

\section{Haemodynamic Parameters \\ Heart Rate}

Observations of our study demonstrated that there was increase in heart rate during laryngoscopy and intubation (T4) and after 1 min of laryngoscopy and intubation (T5) in both groups. However, magnitude of increase in heart rate at T4 and T5 was higher in Group C as compared to Group D and this was statistically significant $(\mathrm{p}=0.013)$ at $\mathrm{T} 4$ and statistically highly significant $(\mathrm{p}=0.005)$ at T5 (Ref: Table No. 2).

Similar to our study, Sameer Arora et al[13] compared dexmedetomidine and clonidine to study haemodynamic responses to intubation and observed that during intubation there was rise in heart rate in both the groups. But it was more in Group C as compared to Group D and this rise in HR in Group $\mathrm{C}$ was statistically significant $(\mathrm{p}<0.05)$ during intubation and after 1 min of intubation. Shirsendu et al[20] compared dexmedetomidine and clonidine for attenuation of sympathoadrenal responses and anaesthetic requirements to laryngoscopy and endotracheal intubation in 60 patients divided into 3 groups of 20 patients each and demonstrated that there was statistically significant rise in heart rate during intubation in clonidine group compared to dexmedetomidine. These findings are in agreement with our results

\section{Blood Pressure/ Systolic Blood Pressure (SBP)}

Our findings demonstrate that the mean SBP rises in both groups at T4 (during laryngoscopy and intubation), T5, T6, T7, T8 $(1,3,5,10$ mins after laryngoscopy and intubation). But it rises more in Group C than Group D, which was highly statistically significant $(p<0.001)$ at T4, T5, T6, T7 and statistically significant $(\mathrm{p}<0.05)$ at T8 between 2 groups (Ref: Table No. 3).

\section{Diastolic Blood Pressure (DBP)}

Mean DBP rises in both groups at T4, T5, T6, T7 and T8. But it rises more in Group $\mathrm{C}$ than Group D which was highly statistically significant $(\mathrm{p}<0.001)$ at $\mathrm{T} 4, \mathrm{~T} 5$ and statistically significant $(\mathrm{p}<0.05)$ at T6, T7 and T8 (Ref: Table No. 4).

\section{Mean Arterial Blood Pressure (MAP)}

Mean Arterial Blood Pressure rises in both groups at T4, T5, T6, T7 and T8. But it rises more in Group C than Group D which was highly statistically significant at T4, T5, T6, T7, T8 (p $<0.001$ ) (Ref: Table No. 5). 
No statistically significant differences were found in the mean systolic blood pressure, mean diastolic blood pressure and mean arterial blood pressure measurements between two groups and both groups were comparable at 20,30, 40, 50, 60, $70,80,90,100,110$ and 120 mins.

Bijoy Kumar et al[21] compared dexmedetomidine and clonidine for sympathoadrenal response and they also found comparatively more increase in SBP with clonidine than dexmedetomidine. These findings are consistent with our results.

Similar to our study, Sameer Arora et al[13] compared dexmedetomidine and clonidine to see haemodynamic responses to intubation and demonstrated that during intubation both groups had maximum rise in SBP, but this was more in Group C than in Group D which was statistically highly significant $(\mathrm{p}<0.001)$.

A Venkateswara et al[22] compared dexmedetomidine and clonidine on induction, haemodynamic and cardiovascular parameters for intubation in general anaesthesia in 90 patients divided into 3 groups of 30 each and observed that after intubation, rise in SBP, DBP, MAP was present in all the 3 groups. But difference between Group NS and Group D was significant and difference between Group NS and Group C was also significant but difference between Group D and Group C was not significant. In our study rise in SBP, DBP and MAP were present in both groups, but difference was statistically significant between Group D and Group C. This can be because they used high dose of clonidine than dexmedetomidine in their study and we used low dose of clonidine.

\section{Sp02}

The mean Sp02 levels remain fairly constant above 95\% in all patients in both the groups. The difference in Sp02 was statistically insignificant at all times. These findings are in concordance with studies conducted by Sameer Arora et al[19] and Shirsendu et al.[20]

\section{$\mathrm{EtCO}_{2}$}

There was statistically insignificant difference in $\mathrm{EtCO}_{2}$ of patients in the 2 groups at all times.

\section{Dose of Anaesthetic Agent}

In our study, the mean dose of propofol used for induction in Group D was $102.20 \pm 13.29 \mathrm{mg}$ and in Group C was $107.80 \pm 11.48 \mathrm{mg}$. There was statistically significant $(\mathrm{p}=$ 0.023 ) reduction in dose required for induction in Group D than in Group C (Ref: Table No. 6).

Similar results were obtained by Shirsendu et al.[20] Aantaa and co-workers have demonstrated the anaesthesia potentiating effects of clonidine and dexmedetomidine. [23,24]

\section{Ramsay Sedation Score}

Mean Ramsay sedation score in Group D was $2.06 \pm 0.239$ and in Group C was $2.04 \pm 0.197$. This was statistically insignificant (Ref: Table No. 6).

This finding is not in concordance with Sameer Arora et al[13] and Shirsendu et al[20] also showed statistically significant difference between dexmedetomidine and clonidine group. This dissimilarity could be due to low dose of dexmedetomidine and clonidine used in our study.

Duration of surgery was statistically insignificant, and it was comparable in both groups ( $\mathrm{p}$ value $>0.05$ ).
In post-operative period, no statistically significant difference was found in mean heart rate, mean systolic blood pressure, mean diastolic blood pressure, mean arterial pressure values, $\mathrm{SpO}_{2}$ measurements and Modified Aldrete Score between two groups ( $p$ value $>0.05$ ).

\section{Adverse Effects}

No patient in our study had bradycardia (HR $<50 \mathrm{bpm}$ ), hypotension (SBP $<90 \mathrm{mmHg}$ or DBP $<60 \mathrm{mmHg}$ or MAP $<50$ $\mathrm{mmHg}$ ), arrhythmias. Vitals were also stable in Post-operative Anaesthesia Care Unit (PACU).

\section{DISCUSSION}

Various studies are done with different doses of alpha-2 agonists (Dexmedetomidine and Clonidine) to attenuate haemodynamic response during laryngoscopy and intubation.

The haemodynamic response to laryngoscopy has been a topic of discussion since 1940. These responses can be detrimental in elderly and haemodynamically compromised patients due to increase in arterial pressure, heart rate and oxygen consumption. Therefore, controlling this perioperative stress response is an important goal of modern anaesthesia.[25,26,27] Many pharmacological methods were evaluated either in premedication or during induction to attenuate haemodynamic responses, but the drugs which were used were either partially effective or they produced undesirable effects.[28]

Dexmedetomidine (Dextro-isomer of medetomidine) was introduced in 1999 and its advantages include sedation, anxiolysis and improved haemodynamic stability by the activation of alpha- 2 receptor located in the post synaptic terminals in the central nervous system, which causes augmentation of vagal activity.[14-17]

Clonidine, an alpha- 2 adrenergic agonist interacts with the catecholaminergic neuronal system which modulates tonic and phasic (reflux) BP control and reduces the release of norepinephrine from nerve endings, both centrally and peripherally.[29]

\section{CONCLUSION}

\section{Based on our Present Study, following Conclusions can be} made-

- Dexmedetomidine has significantly attenuated sympathetic response of laryngoscopy and intubation as compared to clonidine. Thus, our study demonstrated that dexmedetomidine is superior to clonidine in attenuation of haemodynamic response during laryngoscopy and intubation.

- Dexmedetomidine also decreases the dose requirement of anaesthetic agent for induction.

- IV bolus dose of dexmedetomidine $0.5 \mu \mathrm{g} / \mathrm{kg}$ administered 10 mins before laryngoscopy and intubation can be recommended to attenuate the sympathetic response to laryngoscopy and intubation without any side effects.

\section{Limitations of Study}

a. Cost of drug is an important factor and we did not conduct a cost-effectiveness analysis.

b. We did not measure the drug levels in blood. 
c. We did not use bispectral index (BIS) to measure depth of anaesthesia.

\section{Abbreviations}

IV: Intravenous; HR: Heart Rate; SBP: Systolic Blood Pressure; DBP: Diastolic Blood Pressure; MAP: Mean Arterial Blood Pressure; ECG: Electrocardiogram.

\section{REFERENCES}

[1] Miller RD. Monitoring brain state during general anesthesia and sedation. Miller's anesthesia. $8^{\text {th }}$ edn. Elsevier 2015;1:1524-25.

[2] Kaur S, Kataria AP, Kaur G, et al. Comparison of induction characteristics of propofol-lipuro and etomidate-lipuro in cardiac patients in non-cardiac surgery. Int J Sci Study 2014;2(6):66-72.

[3] Yang HS, Kim TY, Bang S, et al. Comparison of the impact of the anesthesia induction using thiopental and propofol on cardiac function for non-cardiac surgery. J Cardiovasc Ultrasound 2014;22(2):58-64.

[4] Reid LC, Brace DE. Irritation of respiratory tract and its reflex effect on heart- surgery. Gynaecology Obstetrics 1940;70:157-62.

[5] Rose DK, Cohen MM. The airway: problems and predictions in 18,500 patients. Can J Anaesth 1991;41(5 Pt 1):372-83.

[6] Chraemmer-Jorgenson B, Hertel S, Strom J, et al. Catecholamnine response to laryngoscopy and intubation. The influence of three different drug combinations commonly used for induction of anaesthesia. Anaesthesia 1992;47(9):750-6.

[7] Kumar. Blocking glossopharyngeal \& superior laryngeal nerves to attenuate the cardiovascular response to laryngoscopy \& endotracheal intubation. IJA 1993;41:20-5.

[8] Denlinger JK, Ellison N, Ominsky AJ. Effects of intratracheal lidocaine on circulatory responses to tracheal intubation. Anaesthesiology 1974;41(4):40912.

[9] Dahlgren N, Messeter K. Treatment of the stress response to laryngoscopy and intubation with fentanyl. Anaesthesia 2007;36(11):1022-6.

[10] Prys RC, Foex P, Biro GP, et al. Studies of anaesthesia in relation to hypertension versus adrenergic $ß$ receptor blockade. Br J Anaesth 1973;45(7):671-81.

[11] Puri GD, Batra YK. Effect of nifedipine on cardiovascular response to laryngoscopy and intubation. Br J Anaesth 1988;60(5):579-81.

[12] Bloor BC, Flacke WE. Reduction in halothane anaesthetic requirement by clonidine, an alphaadrenergic agonist. Anaesth Analg 1982;61(9):741-5.

[13] Arora S, Parikh H, Karia S, et al. A comparative study of haemodynamic responses to intubation: dexmedetomidine $1 \mu \mathrm{g} / \mathrm{kg}$ vs clonidine $1 \mu \mathrm{g} / \mathrm{kg}$. International Journal of Biomedical Research 2014;5(12):721-4.

[14] Wijeysundera DN, Naik JS, Beattie WS. Alpha-2 adrenergic agonists to prevent perioperative cardiovascular complications: a meta-analysis. Am J Med 2003;114(9):742-52.

[15] Hall JE, Uhrich TD, Barney JA, et al. Sedative, amnestic and analgesic properties of small-dose dexmedetomidine infusions. Anesth Analg 2000;90(3):699-705.

[16] Ebert T, Maze M. Dexmedetomidine: another arrow for the clinician's quiver. Anesthesiology 2004;101 (3):568-70.

[17] Gerlach AT, Dasta JF. Dexmedetomidine: an updated review. Ann Pharmacother 2007;41(2):245-52.

[18] Ghignone M, Quintin L, Duke PC, et al. Effects of clonidine on narcotic requirements and hemodynamic responses during induction of fentanyl anaesthesia and endotracheal intubation. Anesthesiology 1986;64(1):36-42.

[19] Flacke JW, Bloor BC, Flacke WE, et al. Reduced narcotic requirement by clonidine with improved hemodynamic and adrenergic stability in patients undergoing coronary bypass surgery. Anesthesiology 1987;67(1):11-9.

[20] Mondal S, Mondal H, Sarkar R, et al. Comparison of dexmedetomidine and clonidine for attenuation of sympathoadrenal responses and anesthetic requirements to laryngoscopy and endotracheal intubation. Int J Basic Clin Pharmacol 2014;3(3):501-6.

[21] Panda BK, Singh P, Marne S, et al. A comparison study of dexmedetomidine vs clonidine for sympathoadrenal response, perioperative drug requirements and cost analysis. Asian Pacific Journal of Tropical Disease 2012;2(Suppl 2):S815-21.

[22] Rao AV, Sreelatha V, Kumar MV. Dexmedetomidine and Clonidine on induction, hemodynamic and cardiovascular parameters for intubation in general anesthesia cases a comparative study. IOSR Journal of Dental and Medical Sciences 2015;14(1):57-68.

[23] Aantaa R, Scheinin M. Alpha 2-adrenergic agents in anaesthesia. Acta Anaesthesiol Scand 1993;37(5):43348.

[24] Quintin L, Bonnet F, Macquin I, et al. Aortic surgery: effect of clonidine on intraoperative catecholaminergic and circulatory stability. Acta Anaesthesiol Scand 1990;34(2):132-7.

[25] Shribman AJ, Smith G, Achola KJ. Cardiovascular and catecholamine responses to laryngoscopy with or without tracheal intubation. $\mathrm{Br} \mathrm{J}$ Anaesth 1987;59(3):295-9.

[26] Saif GM, Singh V, Kumar A, et al. A study of cardiovascular response during laryngoscopy and intubation and their attenuation by ultra-short acting beta-blocker esmolol. Indian J Anaesth 2002;46(2):104-6.

[27] Joris JL, Chiche JD, Canivet JL, et al. Hemodynamic changes induced by laparoscopy and their endocrine correlates: Effects of clonidine. J Am Coll Cardiol 1998;32(5):1389-96.

[28] Roy S, Rudra A, Gupta K, et al. Attenuation of cardiovascular response to laryngoscopy and tracheal intubation with oral clonidine (arkamine). Indian J Anaesth 1993;41(2):62-6.

[29] Virtanen R, Savola JM, Saano V, et al. Characterisation of selectivity, specificity and potency of medetomidine as an alpha 2-adrenoceptor agonist. Eur J Pharmacol 1988;150(1-2):9-14. 